\title{
Design and Practice of project management system for the Project Management of College Students' Innovative and Entrepreneurial Training Program
}

\author{
Liucheng Zhang ${ }^{1, a}$ \\ ${ }^{1}$ The practice teaching management center,Harbin University of Commerce,Harbin,China \\ azhangliucheng@126.com
}

Keywords: Information technology; Management system; Application research

\begin{abstract}
The paper covers the research on the application of Information System to the Training Program .The paper mainly refers to the structure and function of intelligent management system of Innovative and Entrepreneurial Training Program .Besides ,it also touches on the application ,the informatization management in the project review ,management of project process ,information management of assistance ,monitoring and supervision on project research as well as informatization management of project funds .At the end of the paper ,the article concludes effects of Informatization Management on the College Students' Innovative and Entrepreneurial Training Program in Harbin University of Commerce , and make a positive attempted research on the innovation of the the management style and means of the College Students' Innovative and Entrepreneurial Training Program in Provincial Colleges and Universities .
\end{abstract}

\section{Raise the Question}

Harbin University of Commerce (abbr: HUC) has got 89 national-level projects, 61 provincial-level projects and 362 school-level projects since $2012^{[1]}$. Through operation and management of these projects, the problems we have discovered involves in many aspects. For instance, it is not easy to have a choice because applied project and people cover a wide range and quality of project is also rather spotty. It is also difficult for us to invite some advisers, and coordination work is not simple ${ }^{[2]}$. Within the confinement of time and space, communication between teacher and student is limited. We have very little control over establishment, verification, defense of project and its fairness. We also difficultly take control of schedule so that we cannot accomplish the project on time. It is wide coverage area and large number that make summary statistics difficult ${ }^{[3]}$. Especially, storing the paper materials in a long period has not been done easily, which is not beneficial to refer and check. And how to manage research project fund and how to control effectively time arrangement are not simple problems to resolve on account of long-time span and complex procedure ${ }^{[4]}$.

Serving for student and instructor is our duty of project management department. Through effective management, every valuable and meaningful project will be done smoothly, which makes students have the opportunity to participate in it, stimulates student's innovative thinking and awareness, develops student's entrepreneurial skill, creates innovative culture and thus improves the teaching quality ${ }^{[5]}$. In order to solve the problems mentioned above and meet the requirement of innovative and entrepreneurial training program, we began to explore management method and process management mechanism, design and develop intelligent management system of innovative and entrepreneurial training program at Harbin University of Commerce in 2012, which has been put into usage and operation since 2013.

\section{Structure and Function of Intelligent Management System}

Functions of management system runs through the entire process of college students' innovative and entrepreneurial training program, including project application, project review, project release, 
project contact, progress report, mid-term report, concluding report, result tracking, funds management, mutual communication between instructor and student and expert review. It is automatically collecting and statistical query of data that can monitor the project process, which has truly realized paperless office, network and informatization in the process of project management.

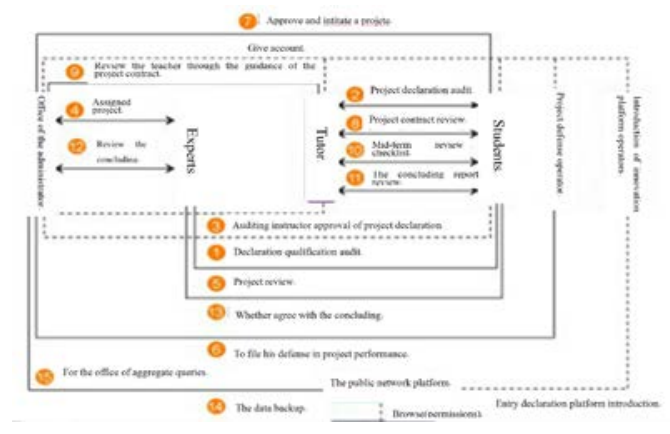

Fig. 1,Structure and Function of Intelligent Management System

\section{Informatization Management of Project Application and Review}

Project Application Management.Send Project Application Notice Timely and Accurately.In accordance with government documents from Ministry of Education and Provincial Educational Department, drawing up and sending the notice timely and accurately to the related department and people will stimulate teacher and student's enthusiasm. Wide publicity with a class as a group will also make preparations for project application and choice. On the other hand, we will post this piece of information in the first place on the school website for teacher and student to consult.

Application Management of 3+2 Program.Project Project application at HUC has to go through college, university, province and more according to related regulation of HUC, namely, on the bases of student's college-level project applications, colleges will invite some experts from their own college to review these projects and then recommend them to university; they will be evaluated by experts from the University and recommended again as provincial or national scientific research project. These recommended projects will be optimally managed by center of practical teaching management and colleges in combination of some practical links, such as opening laboratory, student's competition and bachelor's degree thesis. Optimization of application process and paperless office are attributed to intelligent management system of innovative and entrepreneurial training program, by which students can fill in the material of project application and experts from colleges and university can finish project evaluation.

Management of Project Review.The process of project review covers student's online application, initial college evaluation, anonymous review from the university and public review from the university defense meeting to choose high-quality project by following the principle of openness, fairness and impartiality. With regard to the criteria for evaluation, we mainly focus on key disciplines, brand majors, characteristic and strategic majors and then cover gradually the other disciplines and majors. By taking some measures, the opportunity to study in these projects can be taken by the large number of teacher and student within a short time. By working hard for years, management information system for expert database has been established, by which we can randomly choose experts and realize anonymous review for projects and thus ensure fairness and impartiality.

Management of Project Source.Projects in HUC come from many aspects at present. Included is research project given on bases of school-running features of this specialty, research and innovation project needed by combing fine course construction with course teaching model reform, research subject announced by each center of practical teaching, project chosen by student individually and in groups in accordance with research expertise, social research project and the other valuable research and practice project, which can be managed by using information management system to avoid the content duplication and ensure innovation of newly applied projects. 
Multi-direction choice of Student Leader, Project Member and Tutor.It is information management system that has realized multi-direction choice between instructor and student. That is to say, colleges firstly implement qualification examination for teacher and student, who have two-way choice on the bases of research project. In accordance with the result, teams of expert make the review and argument about projects. Finally, student leaders who have passed the interview set up teams of student's research. Student's leaders, project members and tutor make multi-direction choice and optimize team of research.

\section{Management of Project Process}

Management of Proposal Presentation.CNKI system of duplication checking has been used to check out proposal presentation for all the projects. Experts are organized to carry out anticipated instruction for every step of research project to correct some potential problems, to carry out detailed instruction for research process, project budget and work among members to change those projects which need replacing member, person-in-charge and instructor after discussion, which would ensure that project research continue smoothly.

Mid-term Examination.In finishing half of research project, persons in charge can submit directly mid-term examination report, whose content includes difficulties, problems, project progress and the next work plan. Management department will organize mid-term examination and propose the improved suggestion. During the course of project, if personnel change, content and title alteration appear on account of different reasons, project leader will be required to fill in application and wait for approval from college and management department. Instructor and students who fail to finish the projects will be marked in intelligent management system and will not be permitted to apply the project within one year.

Conclude the Project .After finishing the project, team of project should fill in comprehensive research report of college students' innovative and entrepreneurial training program and attach the related material, research result and physical evidence, which will be examined by experts who management department organizes. When material and vital data provided by team of project is not true and complete or when team of project changes research objective and content without permission, these projects will not be accepted. Instructors and students will be marked in intelligent management system and cannot apply for any project of college students' innovative and entrepreneurial training program within two years.

\section{Informatization Management of Assistance, Monitoring and Supervision on Project Research}

Assistance Function.Through online training and lecture of related project provided by System, students can get corresponding helpful information according to what they want. System also provides link of lab opening platform and soften the terms in lab opening and input and output of experiment equipment, which will be beneficial to progress of project research.

Monitoring Function.On bases of project task book and in combination of project progress, system can carry out humanized message tone and thus guarantee project completion without missing anything. In the light of research content, scheduling and work among members, system can also urge members of project team to finish their own task on time.

Supervision Function.Members of project team can submit in management system the logbook, meeting record in group, tutor's guidance and investigation material, against which management department can examine progress in research project, fund management and evaluate phrased result.

Informatization Management of Project Funds.Funds management adopts funds rendering process of "leader of project is in charge, tutor and leader of college checks and management department approves”, namely, with leader of project filling out an expense report, leader can receive project funds at accounting department after instructor and leader of college examine and management department approves. During the period of this process, amount paid and item of 
expenditure will be written on line by leader of project. With instructor and leader of college checking on line and signing, students can download and print evidence for reimbursement according to number formed automatically by intelligent management system, which will simplify the process for reimbursement for instructor and students and implement real-time statistics to funds outlay and improve efficiency for management department.

\section{Effects of Informatization Management}

Increasing the Number of Projects, Fruitful.As the first batch of approved project unit of college students' innovative and entrepreneurial training program in Heilongjiang province, Harbin University of Commerce has finally got 70 national-level and 20 provincial-level projects of college students' innovative and entrepreneurial training program from 2012 through 2013. Project operation being good, 241 projects have passed final examination from colleges and HUC. More than 600 theses as research results have published at provincial and national periodicals, including 18 theses at national-level core periodicals. 22 patents and 210 entrepreneurial plan books have been accomplished respectively.

Give Priority To the Cultivation of Students, Achieve the Dreams of Venture Company.In In recent years, thanks to the joint efforts of the departments of school teaching practice management center, the Communist Youth League, school work and two grade school, the training program has focused on cultivating a number of typical projects. Since 2012, the number of students participating in the practice of the entrepreneurship of college students has significantly increased , with a total of 86 people directly involved in the venture project practice, and 8 entity companies registered . The number of the students involved in work study programs and other forms of participation in the practice of the project has risen up to more than 400 .

\section{Conclusion}

Development and practice of intelligent management system helps to supervise the entire project process, which ensures finishing project management in high quality and efficiency. Realize this kind of communication "humanized message tone" and finished the task in time. Log function has been used for the purpose of supervising progress in student's project. Distance evaluation from experts, such as online anonymous examination and online defense, has been turned into reality. Included is budget for project money, valid control for expenditure, automatic collection for results and query. All these things mentioned above can contribute to management and implementation of school- level, provincial-level and national-level projects in an order, scientific and high-efficient way, which has also done a useful exploration for innovating talent-trained model and establishing project management mechanism of innovative and entrepreneurial training program.

\section{References}

[1] Gao Yuan, College students' innovative entrepreneurial training plan of project process management research and exploration [J], Journal of laboratory science, 2013 (6), pp. 71-74.

[2] Yang Weizhi, Using the simulation system to cultivate students ability of enterprise management [J], Journal of laboratory research and exploration, 2013, no. 4, pp. 11-13.

[3] Zhang Li,Applied talents cultivation of innovative thinking mode exploration [J], China's higher education, 2012, (19) , pp.12-13

[4] Chen Yinping, Yin Long, College students' innovative entrepreneurial training plan to carry out the practice and exploration, in Harbin university of commerce, for example [J], Journal of new economy, 2014,(15) , pp. 41-54.

[5] Si Songmen, Zhuang Yale, Thinking about college students' innovative entrepreneurial training program [J], Journal of heilongjiang education (higher education research and evaluation), 2014, (7) , pp. 31-33. 